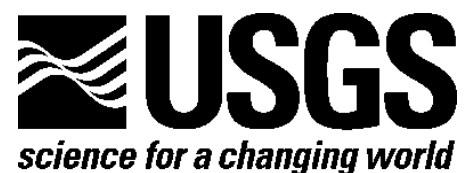

\title{
Capacitively Coupled Resistivity Survey of the Levee Surrounding the Omaha Public Power District Nebraska City Power Plant, June 2011
}

By Bethany L. Burton and James C. Cannia

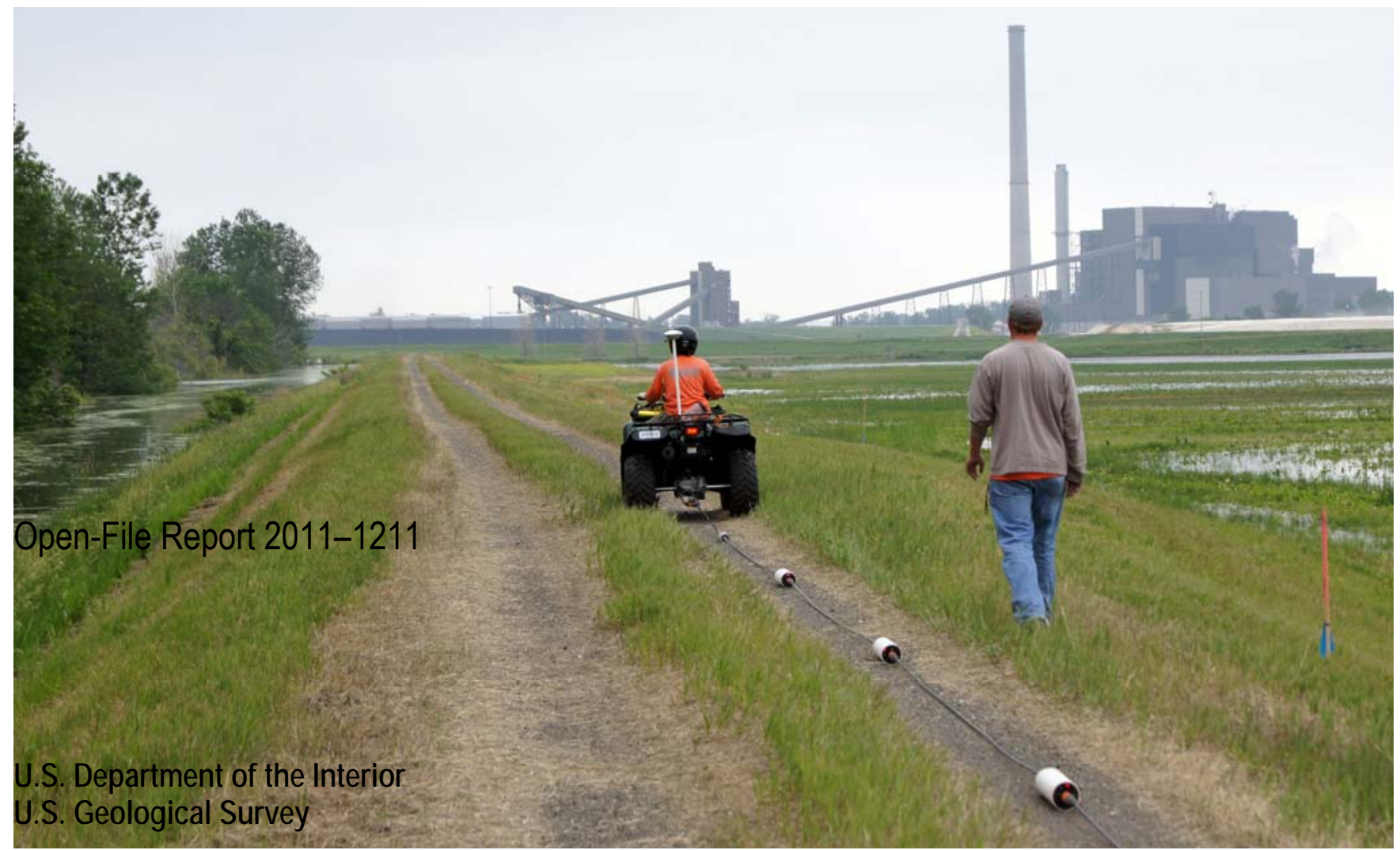




\section{U.S. Department of the Interior \\ KEN SALAZAR, Secretary}

\section{U.S. Geological Survey \\ Marcia K. McNutt, Director}

U.S. Geological Survey, Reston, Virginia 2011

For product and ordering information:

World Wide Web: http://www.usgs.gov/pubprod

Telephone: 1-888-ASK-USGS

For more information on the USGS—-the Federal source for science about the Earth, its natural and living resources, natural hazards, and the environment:

World Wide Web: http://www.usgs.gov

Telephone: 1-888-ASK-USGS

Suggested citation:

Burton, B.L., and Cannia, J.C., 2011, Capacitively coupled resistivity survey of the levee surrounding the Omaha Public Power District Nebraska City Power Plant, June 2011: U.S. Geological Survey Open-File Report 2011$1211,10 p$.

Any use of trade, product, or firm names is for descriptive purposes only and does not imply endorsement by the U.S. Government.

Although this report is in the public domain, permission must be secured from the individual copyright owners to reproduce any copyrighted material contained within this report. 


\section{Contents}

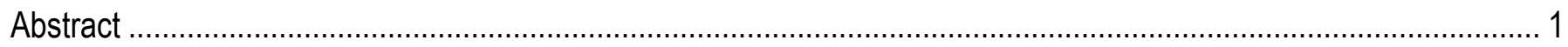

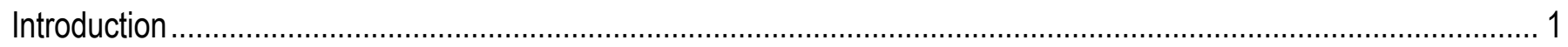

Purpose and Scope

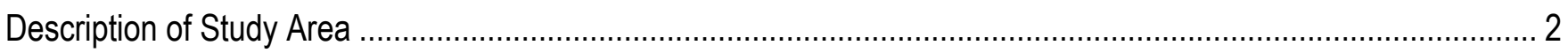

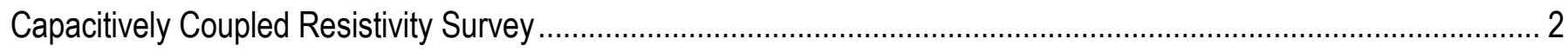

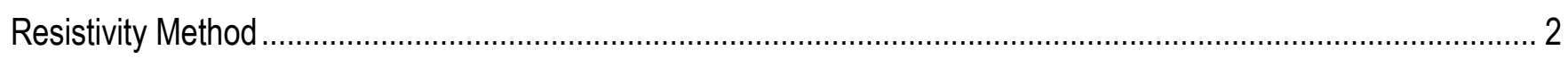

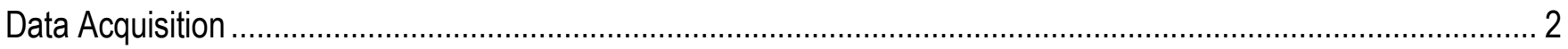

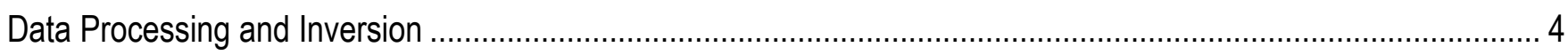

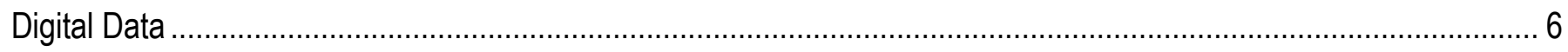

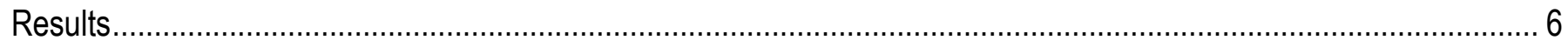

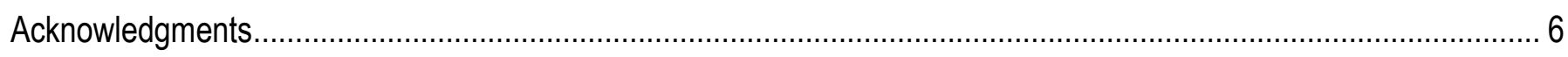

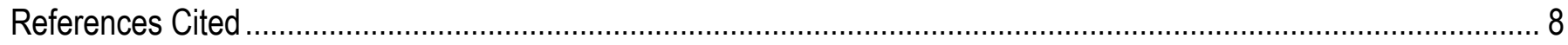

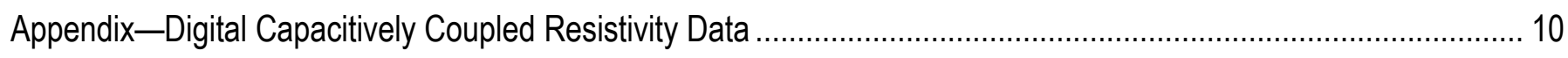

\section{Figures}

Figure 1. Location of study area and capacitively coupled resistivity survey sections on levee 573.

Figure 2. Schematic illustration showing the capacitively coupled resistivity acquisition system setup and geometry (modified from Ball and others, 2006).

Figure 3. Preliminary capacitively coupled resistivity inverted sections acquired along the section of levee 573 surrounding the Omaha Public Power District Nebraska City power plant. The locations of the sections are shown on figure 1. All sections are plotted on the same scale and have a six fold vertical exaggeration. 


\section{Conversion Factors}

SI to Inch/Pound

\begin{tabular}{lll}
\hline \multicolumn{1}{c}{ Multiply } & By & \multicolumn{1}{c}{ To obtain } \\
\hline & Length & \\
\hline centimeter (cm) & 0.3937 & inch (in.) \\
millimeter (mm) & 0.03937 & inch (in.) \\
meter (m) & 3.281 & foot (ft) \\
kilometer (km) & 0.6214 & mile (mi) \\
kilometer (km) & 0.5400 & mile, nautical (nmi) \\
meter (m) & 1.094 & yard (yd) \\
\hline
\end{tabular}




\title{
Capacitively Coupled Resistivity Survey of the Levee Surrounding the Omaha Public Power District Nebraska City Power Plant, June 2011
}

\author{
By Bethany L. Burton and James C. Cannia
}

\begin{abstract}
This report is a release of digital data from a capacitively coupled resistivity survey conducted on June 13, 2011, on the flood-protection levees surrounding the Omaha Public Power District Nebraska City power plant. The U.S. Geological Survey Crustal Geophysics and Geochemistry Science Center and the Nebraska Water Science Center performed the survey in response to a flood on the Missouri River. A single line of resistivity profiling was completed along the center line of the section of levee 573 that surrounds the power plant.
\end{abstract}

\section{Introduction}

Capacitively coupled surveys have been used effectively by the U.S. Geological Survey (USGS) to map the near surface electrical properties of the subsurface to a depth of approximately 10 meters (m) (Ball and others, 2006; Burton and others, 2009). This type of survey provides a nearly continuous resistivity dataset, which can be inverted to provide a distribution of resistivity with depth along a profile. The inverted data can then be correlated to known lithologic data from the area to create a geologic interpretation. The data included in this report have undergone processing and preliminary inversion. Final inversions and geological interpretation can be completed after borehole information concerning lithology at selected locations is available.

\section{Purpose and Scope}

This report presents the capacitively coupled resistivity survey data collected by the USGS on June 13, 2011, on levee 573. This levee protects the Omaha Public Power District (OPPD) Nebraska City power plant. Approximately 7 kilometers $(\mathrm{km})$ of data were collected. The objective of the survey is to map the near subsurface electrical properties, including the levee and the materials immediately below it. To gain a better understanding of the levee construction and the nature of the lithology upon which it rests, this report presents preliminary inversion results as well as the raw and inverted data so that comparisons with available borehole information can be made in the future. 


\section{Description of Study Area}

The USGS performed the survey on the levee surrounding the Nebraska City power plant, which lies approximately $9 \mathrm{~km}$ southeast of Nebraska City, Nebr. Levee 573 was constructed in the floodplain of the Missouri River and has an approximate altitude of $275 \mathrm{~m}$. The levee begins on the northwest corner of the power plant and circles around to the southwest corner. The resistivity survey was split into six sections that ranged from about 0.8 to $1.6 \mathrm{~km}$ long to aid in processing. The section locations are shown in figure 1.

\section{Capacitively Coupled Resistivity Survey}

\section{Resistivity Method}

Resistivity is the property of a material that opposes the flow of electric current. Measurements are made by injecting a known current into the subsurface using two current electrodes and measuring the resulting voltage difference between two potential electrodes. Based on Ohm's Law, the resistance is computed by taking the ratio of the measured voltage and the transmitted current. The apparent resistivity of the material, expressed in ohm-meters (ohm-m), is then determined by multiplying each resistance value by the corresponding geometric factor, which is based on the electrode geometry and spacing.

The main factors that affect the resistivity of a material are the amount of interconnected pore water present, the water quality (level of total dissolved solids (TDS)), and the amount of mineralogical clay present. In the unsaturated zone, if no mineralogical clay is present, a fine-grained material (for example, silt or fine sand) will generally retain more interconnected water due to capillary forces than a coarse-grained material (for example, coarse sand or gravel). The fine-grained material will therefore have a lower resistivity compared to coarser-grained materials. In the saturated zone, water quality is an important factor because the concentration of ions in the water affects its ability to conduct electricity. Materials containing water with high TDS levels will have a lower resistivity compared to materials containing water with low TDS levels. The presence of even a small amount of mineralogical clay can dramatically decrease the overall bulk resistivity of a material because current is conducted both through the pore fluids (electrolytically) as well as through cation exchange (electronically). Because of the relation between grain size and resistivity, the resistivity method can be a useful tool in differentiating lithologies to identify paleochannels or other coarser-grained deposits that could lead to preferential flow paths below the levee foundation during high-water events. Reynolds (1997), Sharma (1997), and Butler (2005) provide more detailed descriptions of the resistivity method and resistivity values for common geologic materials.

\section{Data Acquisition}

The capacitively coupled (CC) resistivity data were acquired with the Geometrics OhmMapper TR5 (Geometrics, Inc., San Jose, Calif., U.S.A.) towed behind an all-terrain vehicle (ATV) and integrated with a Trimble DSM 232 (Trimble Navigation Ltd., Sunnyvale, Calif., U.S.A.) differential global positioning system (DGPS) unit with the OmniSTAR (OmniSTAR, 2005) High Precision (HP) subscription service. This dipole-dipole resistivity array system comprises five receiver dipoles (equivalent to five potential electrode pairs) and one transmitter dipole (equivalent to a current electrode 


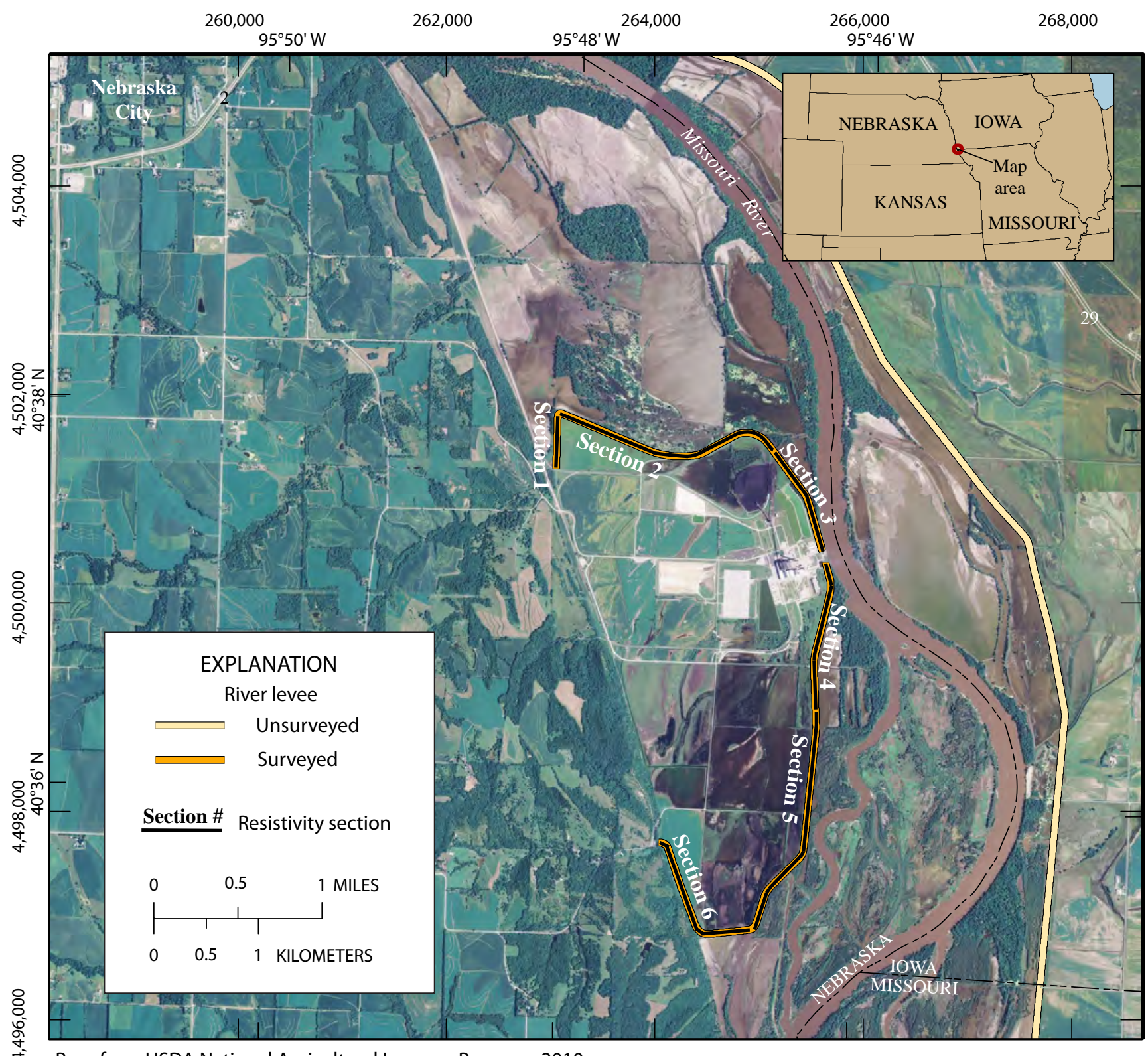

Base from USDA National Agricultural Imagery Program, 2010

Universal Transverse Mercator projection, zone 15 north

North American Datum of 1983

Figure 1. Location of study area and capacitively coupled resistivity survey sections along levee 573. 
pair; fig. 2). Each dipole consists of a 5-m cable attached to each end of an electronics unit, which results in dipole lengths of $10 \mathrm{~m}$. The resultant towed array length is approximately $50 \mathrm{~m}$.

The transmitter, located at the rear of the array, is attached to the receivers by a nonconductive rope (5 m long for this survey) and transmits an alternating current at a frequency of 16.5 kilohertz (kHz). Current is transmitted into the ground through the use of capacitance; this negates the need for the electrodes to be in direct contact with the ground and thus allows for more efficient and faster data acquisition. The wire in each dipole cable and the ground act as the opposing conductor "plates" of a capacitor, and the insulating sheath of the wire and air between the dipole cable and the ground act as the insulator between the plates (Geometrics, 2001).

Each receiver dipole samples the subsurface to a particular depth based on its length and distance from the transmitter dipole. Based on the survey objective, the survey is designed to create the optimal compromise between vertical and horizontal resolution and maximum depth of investigation by varying the geometry (dipole and rope lengths) of the array. Both the CC resistivity and DGPS data are acquired at a rate of 1 Hertz $(\mathrm{Hz})$ with the ATV traveling from 3 to $5 \mathrm{~km} / \mathrm{hr}$, producing, on average, a measurement density of about 3 to 5 data points per meter for each transmitter-receiver dipole pair. For further details on the capacitively coupled resistivity method and acquisition system, refer to Timofeev and others (1994), Geometrics (2001), Ball and others (2006), Lucius and others (2008), and Burton and others (2009).

\section{Data Processing and Inversion}

The raw binary data files were downloaded from the OhmMapper instrument using Geometrics MagMap2000 version 4.90 software (Geometrics, 2009). The binary files were imported into a pair of USGS GPS and OhmMapper data-processing software programs named GPSpathtool and OhmBin, respectively. In GPSpathtool, the geographic positions in the imported raw binary file are automatically projected to the appropriate NAD83 UTM zone in meters. The position and elevation of the center of each transmitter-receiver dipole pair for every measurement is interpolated and extrapolated from the National Marine Electronics Association (NMEA) GGA message string (includes time-, position-, and fix-related data). The data are mapped, or projected, to the path fit and imported into the OhmBin program where the resistivity data can be viewed and processed.

Within the OhmBin program, the data can be viewed as either line plots for each receiver or as contoured pseudosections of the apparent resistivity, measured voltage, calculated resistance $(\mathrm{mV} / \mathrm{mA})$, and transmitted current levels. The data were processed by (1) automatically removing data spikes using a single data-point-spike width and factor of 1.5, (2) manually removing obvious data spikes in the voltage and resistance data, and (3) binning (or averaging) the data to a 5-m bin size.

The binned data are exported in a RES2DINV (Loke, 2011) data format that can also be imported into Advanced Geosciences, Inc. (AGI), EarthImager 2D (Advanced Geosciences, Inc., 2008) inversion program. This format does not contain the true projected coordinates of the data, only the downline distance and elevation information. Upon export from OhmBin, an EarthImager 2D format elevation file is also created that is used during the optimized finite-element inversion. All CC resistivity data were inverted using the robust inversion method in EarthImager 2D version 2.4.0 build 617. The robust method is based on the assumption of an exponential distribution of data errors and minimizes an L1norm parameter that is a combination of the model data misfit and stabilizing function. The method typically performs well on noisy datasets and resolves resistivity boundaries well (Advanced Geosciences, Inc., 2008). 


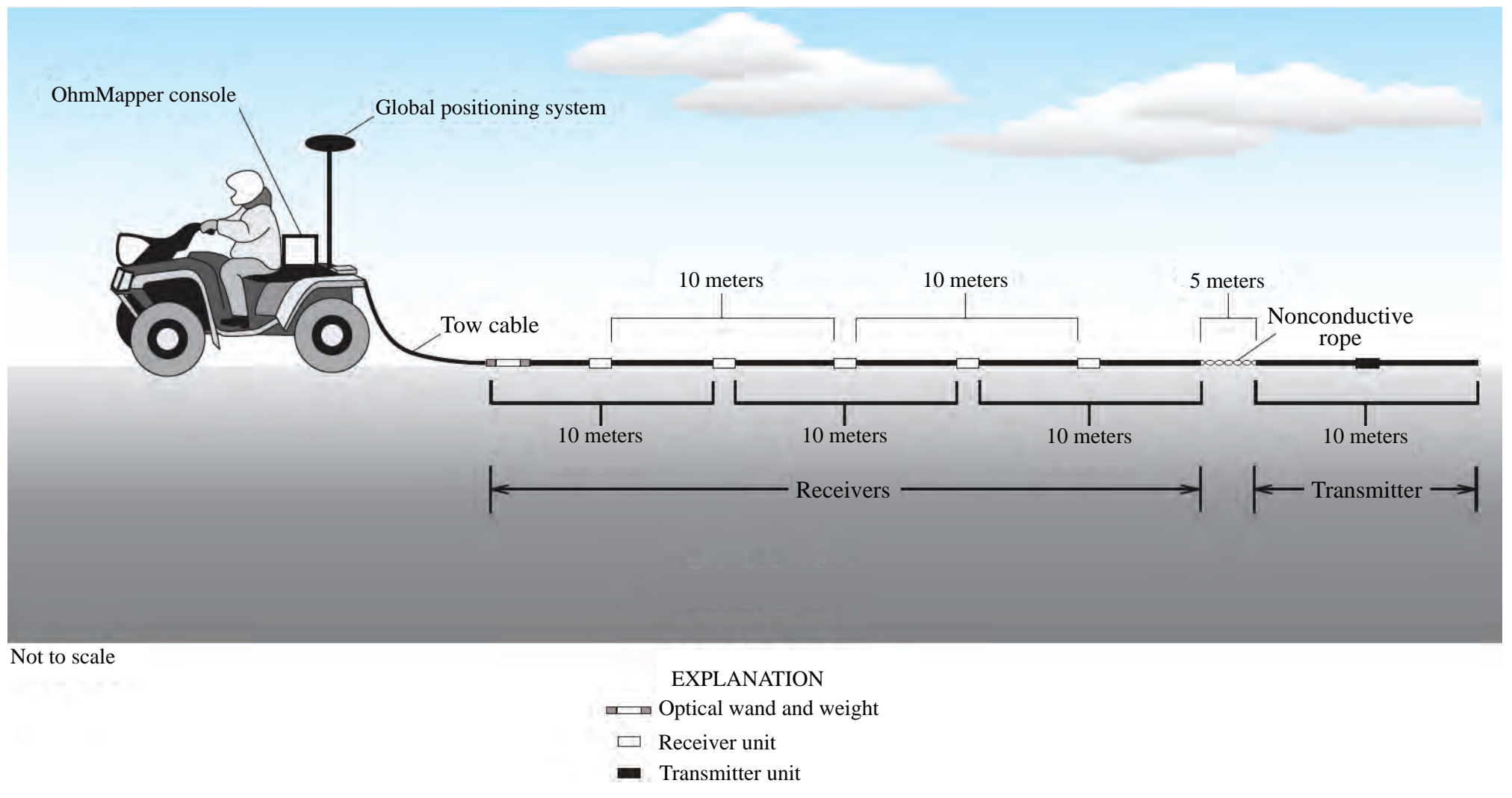

Figure 2. Schematic illustration showing the capacitively coupled resistivity acquisition system setup and geometry (modified from Ball and others, 2006). 


\section{Digital Data}

The raw and preliminary inversion CC resistivity data are provided as an appendix to this report in electronic-text format. See the Appendix for the data format.

\section{Results}

The results of the CC resistivity survey show changes in resistivity with depth within the levees and the underlying material of the floodplain deposits down to a depth of about $10 \mathrm{~m}$ (fig. 3). The resistivity values range from approximately 10 to $100 \mathrm{ohm}-\mathrm{m}$ along the length and depth of the measured section. Although no geologic interpretation has been made by the authors since these are preliminary results that have not been compared in detail with available soil borings, it is believed that lithologic changes, rather than water saturation, are the cause of the observed lateral changes in resistivity. These profiles can therefore be used to differentiate between finer-grained alluvial materials (silt and clay), which generally exhibit lower electrical resistivity values (cooler colors in fig. 3), and coarser-grained alluvial materials (sand and gravel), which exhibit higher resistivity values (warmer colors in fig. 3). Coarser-grained materials generally have a higher capacity to transmit water than finergrained materials (silt and clay), as would be expected in paleochannel deposits that typically exist in a river floodplain environment. It is these coarser-grained deposits that have the most potential for leakage through and under the levees.

\section{Acknowledgments}

The authors wish to thank the Omaha Public Power District for providing access and support during the survey. We also thank Lyndsay Ball and Jared Abraham, USGS, for their help in preparing this report. 

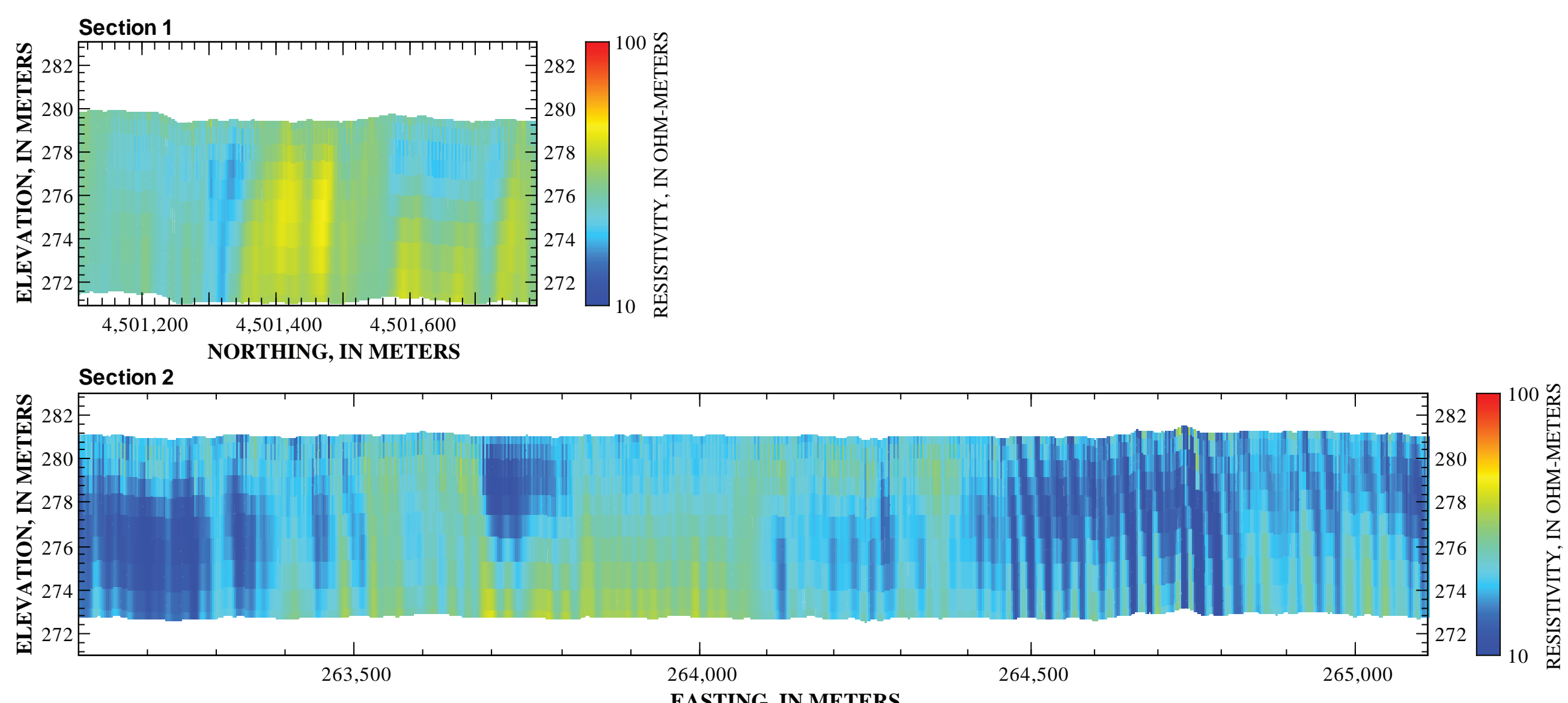

EASTING, IN METERS
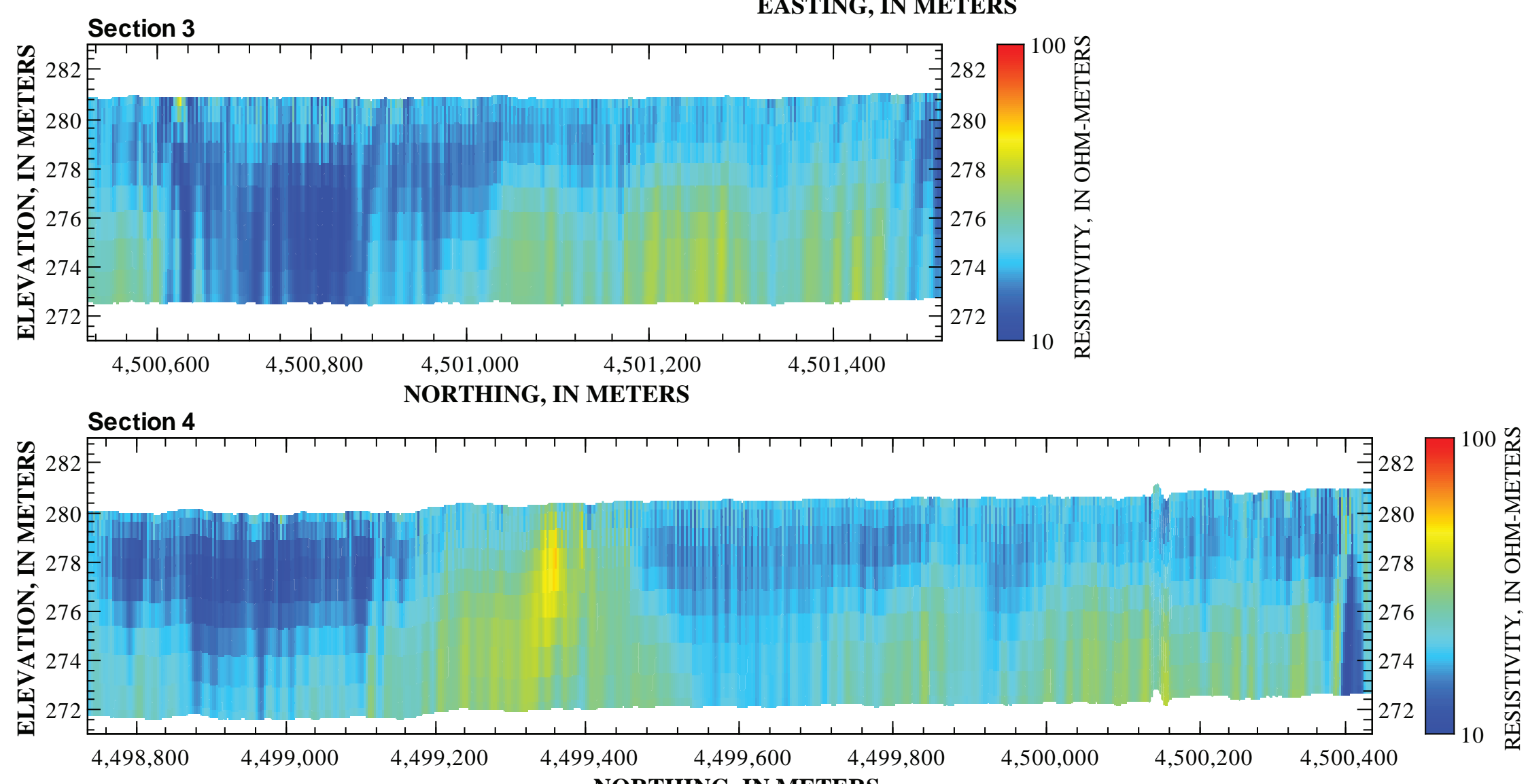

NORTHING, IN METERS
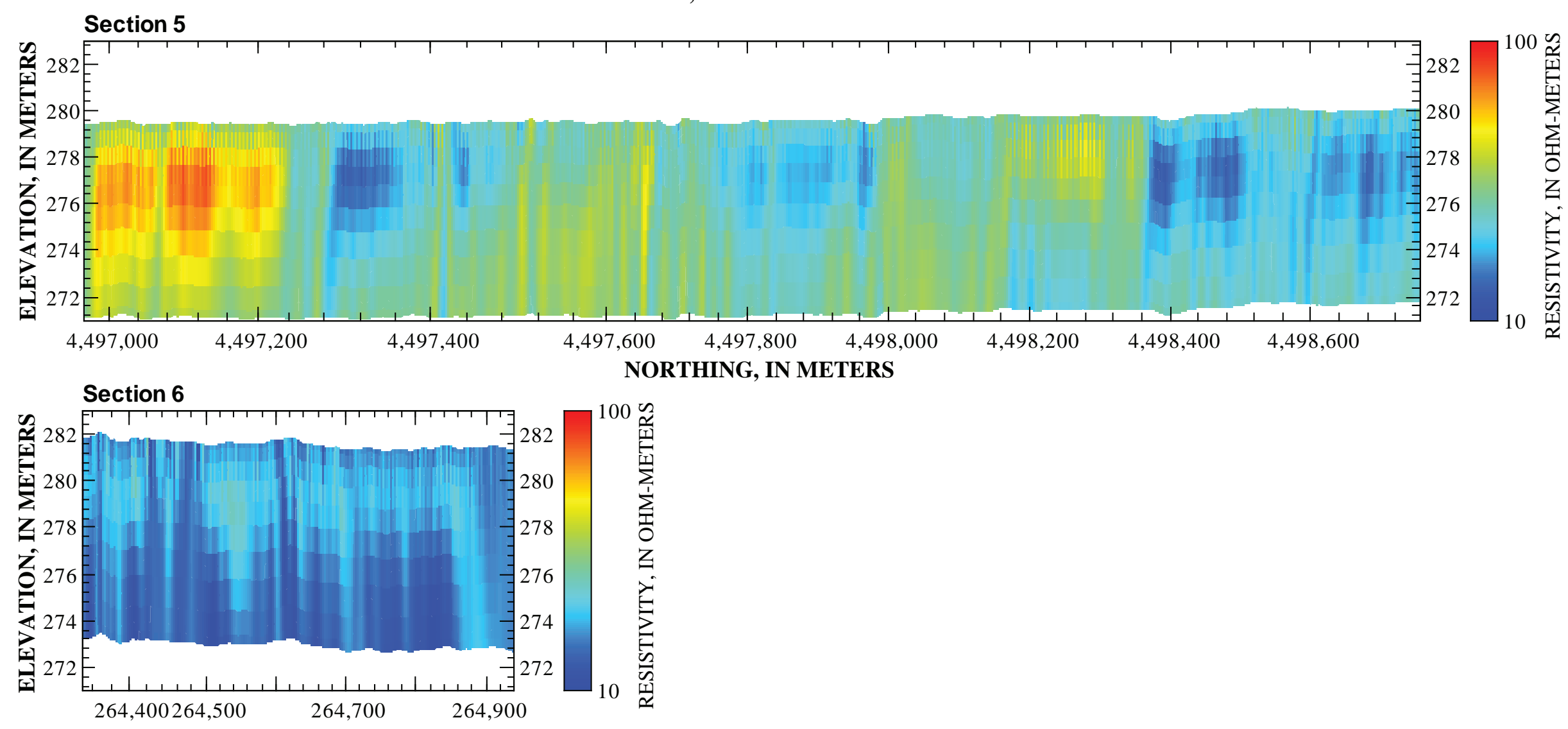

EASTING, IN METERS

Figure 3. Preliminary capacitively coupled resistivity inverted sections acquired along the section of levee 573 surrounding the Omaha Public Power District Nebraska City power plant. The locations of the sections are shown on figure 1. All sections are plotted on the same scale and have a six fold vertical exaggeration. 


\section{References Cited}

Advanced Geosciences, Inc., 2008, Instruction manual for EarthImager 2D version 2.3.0—Resistivity and IP inversion software: Austin, Tex., Advanced Geosciences, Inc., 139 p.

Ball, L.B., Kress, W.H., Steele, G.V., Cannia, J.C., and Andersen, M.J., 2006, Determination of canal leakage potential using continuous resistivity profiling techniques, Interstate and Tri-State Canals, western Nebraska and eastern Wyoming, 2004: U.S. Geological Survey Scientific Investigations Report 2006-5032, 53 p. (Also available at $h t t p: / / p u b s . u s g s . g o v / s i r / 2006 / 5032 /$.

Burton, B.L., Johnson, M.R., Vrabel, Joseph, Imig, B.H., Payne, J.D., and Tompkins, R.E., 2009, Capacitively coupled resistivity survey of selected irrigation canals within the North Platte River valley, western Nebraska and eastern Wyoming, 2004 and 2007-2009: U.S. Geological Survey Scientific Investigations Report 2009-5194, 70 p. (Also available at http://pubs.usgs.gov/sir/2009/5194/.)

Butler, D.K, ed., 2005, Near-surface geophysics_-Investigations in geophysics No. 13: Tulsa, Okla., Society of Exploration Geophysicists, 732 p.

Geometrics, 2001, OhmMapper TR1 operation manual rev. F: San Jose, Calif., Geometrics, Inc., 147 p., accessed July, 2011, at ftp://geom.geometrics.com/pub/GeoElectric/Manuals/OhmMapper-ManualTRN-2004.PDF.

Geometrics, 2009, MagMap2000 4.0 user guide rev. H: San Jose, Calif., Geometrics, Inc., 235 p., accessed July, 2011, at http://www.geometrics.com/geometrics-products/geometricsmagnetometers/download-magnetometer-software/.

Loke, M.H., 2011, RES2DINV ver. 3.71 manual—Rapid 2D resistivity and IP inversion using the leastsquares method: Penang, Malaysia, Geotome Software, 162 p., accessed July, 2011, at http://www.geoelectrical.com/downloads.php.

Lucius, J.E., Abraham, J.D., and Burton, B.L., 2008, Resistivity profiling for mapping gravel layers that may control contaminant migration at the Amargosa Desert Research Site, Nevada: U.S. Geological Survey Scientific Investigations Report 2008-5091, 30 p. (Also available at http://pubs.usgs.gov/sir/2008/5091/.)

OmniSTAR, 2005, High precision subscription service: Houston, Tex., OmniSTAR, Inc., accessed July, 2011, at http://www.omnistar.com/faq.html.

Reynolds, J.M., 1997, An introduction to applied and environmental geophysics: Chichester, England, Wiley, 796 p.

Sharma, P.V., 1997, Environmental and engineering geophysics: Cambridge, United Kingdom, Cambridge University Press, 475 p. 
Timofeev, V.M., Rogozinski, A.W., Hunter, J.A., and Douma, M., 1994, A new ground resistivity method for engineering and environmental geophysics, in Symposium on the Application of Geophysics to Engineering and Environmental Problems, Boston, Mass., March 27-31, 1994, Proceedings: Denver, Colo., Environmental and Engineering Geophysical Society, p. 701-715. 


\section{Appendix-Digital Capacitively Coupled Resistivity Data}

Digital capacitively coupled resistivity data are provided in two compressed files:

1. Lev573_CCres_BIN.zip: processed, binned (5-m bin size) data, and

2. Lev573_CCres_INV.zip: processed, inverted model (2.5-m cell size) data.

All data are provided in an ASCII array, comma-separated format. Unavailable or null data are denoted by a -9999.00 value. The data headings are as follows:

- Section: CC resistivity data-section number;

- $X$ and $Y$ : easting and northing coordinates of acquired CC resistivity data in NAD83, UTM zone $15 \mathrm{~N}$, in meters;

- Z: elevation of acquired CC resistivity data in NAVD88, in meters;

- Dist_m: local downline distance for each section, in meters;

- Elev_m[\#]: elevation horizontal array containing \# values, in meters; and

- Res_ohmm[\#]: resistivity value horizontal array containing \# values, in ohm-m.

In the binned data file, the Elev_m[\#] and Res_ohmm[\#] headings are array values containing 5 elements each for every X and Y location. The Res_ohmm[\#] heading contains apparent resistivities, in ohm-m.

In the inverted data file, the Elev_m[\#] and Res_ohmm[\#] headings are array values that contain 11 elements for every $\mathrm{X}$ and $\mathrm{Y}$ location, except for section 6, which contains 10 elements. 